\title{
Effect of Learning Interest and Parental Social Support on Social Studies Learning Outcomes
}

\author{
Novi Dwisavitri \\ Graduate School \\ Universitas Negeri Yogyakarta \\ Yogyakarta, Indonesia \\ novidwisavitri@yahoo.co.id
}

\author{
Trie Hartiti Retnowati \\ Graduate School \\ Universitas Negeri Yogyakarta \\ Yogyakarta, Indonesia \\ tri_hartiti@yahoo.com
}

\begin{abstract}
This study has purpose to determine the effect of: (1) Learning Interest on the Learning Outcomes of IPS, (2) Parents Social Support on the Learning Outcomes of IPS, (3) Learning Interest and Parents Social Support on the Learning Outcomes of Social Studies. Subjects in this study were all students of grade VIII MTs NU Salam in academic year of 2017/ 2018, the number of students were 131 students, the data collection technique was done by using questionnaires and documentation. The test of instrument was conducted on 25 students. The test of Validity was done by using a correlation technique of Product Moment proposed by Karl Person, whereas, the test of reliability was performed by using Alpha formula. Before the hypothesis testing was conducted, an assumption test held consisting of normality test, linearity and multicollinearity test. The first and second hypothesis testing was done by using simple regression, whereas, the third hypothesis testing was done by using multiple regression. Based on the results of research, it is concluded that: (1) there is a positive and significant effect of Learning Interest on the Learning Outcomes of Social Studies, with rx1y $=0.317 ; \mathbf{r} 2 \times 1 y=0.100$ and $t_{\text {value }}$ $=3.791$ greater than $t_{\text {table }}$ of 1.658 , (2) there is a positive and significant effect of Parents Social Support on the Learning Outcomes of Social Studies, with $\mathbf{r x 2 y}=0.349$; $\mathbf{r} 2 \mathrm{x} 2 \mathrm{y}=0.122$ and $t_{\text {value }}=4.234$ greater than $t_{\text {table }}$ of 1.658, (3) there is a positive and significant effect of Learning Interest and Parents Social Support simultaneously on the Learning Outcomes of Social Studies, indicated by $\operatorname{Ry}(1,2)=0.445 ; \operatorname{R2y}(1,2)=0.198$ and $F_{\text {value }}=15.834$ greater than $F_{\text {table }}$ of 3,070. The relative contribution of variable of Learning Interest on the Learning Outcomes of is $44.43 \%$ and the contribution of variable of Parents Social Support on the Learning Outcomes of Social Studies is $55.57 \%$. The Effective contribution of variable of Learning Interest on the Learning Outcomes of Social Studies is $\mathbf{8 . 8 0 \%}$ and the effective contribution of variable of Parent Social Support on the Learning Outcomes of Social Studies is $11.00 \%$. Learning Interest and Parent Social Support simultaneously provide an effective contribution of $19.80 \%$ on the Learning Outcomes of Social Studies.
\end{abstract}

Keywords-Learning Interest, Parent Social Support Parents and Social Studies Learning Outcomes

\section{INTRODUCTION}

The success of a lesson can be measured through the Learning Outcomes. Learning Outcomes are results obtained by students during the learning process. Learning outcomes becomes a benchmark for evaluating the learning activities that have been carried out. To determine the learning outcomes achieved is in accordance to the desired objectives, evaluation can be conducted. Learning evaluation must be done to find out the difficulties and constraints faced by the students. Evaluation is the process of using information to make a judgment on how effective a program has met the needs of students. In addition, the evaluation or assessment can be used as feedback or follow-up, or even to measure students' mastery level. MTs NU Salam is a formal institution equal to Junior High School (SMP) under the Ministry of Religion and Education Foundation Ma'arif Nahdlatul Ulama in Magelang. In the school curriculum set, combines general subjects, subjects of religion and local content. Social Studies (IPS) is one of the general subjects in the school.

Based on the preliminary observation conducted by researcher, obtained results that the learning outcomes of Social Studies students of MTs NU was not maximized. It can be seen in the results of YearEnd Assessment in the academic year of 2017/2018 on Social Studies subject from the VIII grade students of the total number of 131 students, where there were still some students who have not reached the standard of Minimum Learning Achievement. Out of the total 131 students of grade VIII, there were 35 or $26.7 \%$ students who did not complete the achievement.

As seen from the results of the learning achieved, there were still many students of grade VIII who obtained score of Social Studies lower than the minimum learning criteria. This fact indicated that the learning outcomes obtained by the students has not been optimal. Learning Outcomes satisfactory is a dream for students, teachers, and parents. There are several factors that affect student learning outcomes of Social Studies. These factors can be classified into two, namely the factor of the student (internal) and factors outside student (external). The internal factor is divided into two physical factors (health and physical disability) and psychological factors (intelligence, attention interests, talents, motives, maturity and readiness. Meanwhile, the external factors consist of family factors, school factors and community factors.

Learning interest is one of the physical factors, i.e. factors originating from within the students that affect 
the learning outcomes. Despite a lot of research on the influence of Learning Interest on Learning Outcomes, however, there is no adequate information about the effects of Learning Interest on Learning Outcomes of Social Studies of MTs students. Based on the result of preliminary observation conducted in the classroom during the teaching learning process of Social Studies, the student's interest in learning Social Studies was still low. Instead of the internal factors, one of the external factors affecting the learning outcomes is family environment. Here, Family environment means the attitude, attention and support from parents. Social support given by parents to their children will affect the learning outcomes. The Social Support of Parents of students MTs NU Salam which given to their children were still not optimal. Parents were lack of attention and guidance to their children. Based on the results of preliminary observation showed that there were some students who live in boarding schools rarely meet their parents, there were also some students whose parents have divorced so that they are only living with their mother or only with their grandmother and there were students whose parents are working abroad or outside the city. This study focused on two factors suspected to have an influence on Social Studies learning outcomes, namely Learning Interest and Parents Social Support.

\section{THEORETICAL REVIEW}

\section{A. Learning Outcomes of Social Studies}

One of the things that is considered important in the learning activities are of Learning Outcomes. According to the London Communiqué. Elmgren [2] stated that Learning outcomes place the focus on the student and his or her learning, rather than on the teacher and his or her learning, rather than on the teacher and the content of the course, Here, learning Outcomes puts the focus on students and learning, rather than on teachers and learning content.

Social Studies (IPS) is one of the subjects given in SMP/ MTs. The label of IPS in Indonesia was taken from the education in America, named Social Studies. According to the National Council for the Social Studies (NCSS) in Sapriya [7] Social Studies Learning Outcomes is a result obtain by students both in terms of knowledge, attitudes and skills obtained by the students after studying the subject matter of Social Studies expressed in scores obtained from the test results. In this study, Social Studies Learning Outcomes is referred to the result obtained by students in the cognitive aspects of knowledge or taken from the End Year Assessment (PAT) in the academic year of 2017/2018.

\section{B. Learning Interest}

Each student must have an interest in every subject in school. Learning Interest becomes important for students for willing to do the learning activities. According to Nitkho \& Brookhart [5] interest are preferences for specific types of activities when a person is not under external pressure, this is in accordance to Nunnally and Berstein (McCoach, Gable, and Madura [4] who stated that interests as preferences for work activities. Based on both opinions, it can be interpreted that the interest is the choice to shape certain preferred activity when a person is not under pressure from the outside. Learning Interest is as a personal preference about the learning, Lee, et al. [3]. The indicators of Learning Interest in this study include: 1) pay attention to the learning process, 2) show a sense of love to the lesson, 3) an enthusiasm of the students, 4) participate in the learning, 5) show the activeness in learning.

\section{Parental Social Support}

The family is the first place of a child to obtain an education. A family that originated from a father and a mother teaches their children to speak, socialize and do things include giving the social support. Research on social support have been done many times, for example in San Diego University, Walen RH [10] conducted research on social support from spouse, family and friends in which the study stated that the support of families, especially fathers and mothers is the key to success. Taylor [10] stated that social support is information of a loved and cared for, respected and valued, as well as part of the relationship and the mutual obligations. Shen et al [8] stated that "... parental social support were important factors associated with children's enjoyment in school ..." this means that the Social Support of Parent is an important factor associated with the happiness of children in school. Social support given by relatives, the beloved and respected people by an individual will be more beneficial than support given strangers or those who do not have a close relationship with the individual. According to Reber [6] social support are all forms of support provided by individuals and other groups that help an individual to cope with life. Indicators of Parents Social Support including: 1) emotional support, 2) awards support, 3) instrumental support, 4) informative support, 5) network support.

\section{METHODOLOGY}

\section{A. Data}

This study reveals the existing data without giving any treatment or manipulation of the data on the variables studied, thus this study was considered as ex-post facto research. Ex-post facto research is a research conducted to examine the phenomena happened and then review the data to find out the factors that precede or determine the possible causes of the events that being observed. The data is presented, calculated by using simple correlation and multiple correlation to determine the effect of the variables. This method was selected since the study was done is trying to see whether there is an influence of the variables in the research and to determine the strength of the influence of the variable This study was conducted in MTs NU Salam Magelang located 
at Bendosari Salam Magelang on grade VIII. The study was started by conducting previous observation in May 2018. The study was the conducted from June-July 2018. The subject of the study includes all students of grade VIII MTs NU Salam in the Academic Year of 2017/ 2018, the total number of students were 131 students. This study was a population research since all students of grade VIII were taken to participate in the study without any exception.

The documentation in this study was used to obtain data/ information on the learning outcomes of Social Studies (Y) Grade VIII MTs NU Salam in the academic year of 2017/ 2018 by using the score obtained from the End Year Assessment (PAT). Questionnaire in this study was used to obtain data/ information on the Learning Interest (X1) and the data of Parents Social Support (X2). The questionnaire contains a statement addressed to the students of grade VIII MTs NU Salam in the academic year of $2017 / 2018$.

\section{B. Method}

Validity is a measurement that indicates the levels of validity and the validity of an instrument, Arikunto [1]. The research instrument was designed based on the theory, then consulted with experts who are competent in the field of the study (expert judgment) to test the validity of the content. The results of the validity of the experts, and then analyzed the items to test the validity of each item scores within each item correlated with the total score. The correlation coefficient was calculated by using the formula of product moment ( $\mathrm{r}$ ) by using the significant value of $5 \%$ as critical value. Reliability indicates the level of reliability of a reliable trustworthy or reliable. The reliability of instrument used was internal consistency that was done to try the instruments once and then the data obtained were analyzed by using Cronbach alpha technique.

Normality test was used to determine whether the data is in the normal distribution or not. To test the normality of the data distribution was done by using the formula of Kolmogorov-Smirnov by using SPSS. The test of linearity aims to determine whether the relationship between independent variables and the dependent variable is linear (straight line) or not. The test of assumptions of multicollinearity was intended to prove or test whether there is a linear relationship between the one independent variable to another independent variable. The analysis used to test the hypothesis in this study was multiple regression analysis. This analysis was used to test the hypothesis of the 1st, 2nd and 3rd, the effect of Learning Interest and Parents Social Support on Learning Outcomes of IPS grade VIII MTs NU Salam in the academic year of $2017 / 2018$.

\section{RESULT AND DISCUSSION}

The data of variable of Social Studies Learning Outcomes was obtained through the documentation of scores of End Year Assessment (PAT) of the second semester of students grade VIII MTs NU Salam in the academic year 2017/ 21018. Based on the research data which was processed by using SPSS 16.0 for windows the highest score is 95 , the lowest score is 60 , the mean score is 76.13 , median is 78.00 , mode 78 and the standard deviation is 8.416 . Based on the above data, there were 96 student $(73.3 \%)$ who were categorized to complete the standard achievement score and 35 students $(26.7 \%)$ were considered fail or incomplete the standard achievement score.

The data of variable of Learning Interests was obtained from a questionnaire consisting of 22 items of questions. The maximum score given was 4 and minimum 1, therefore, obtained the highest score ideal 88 and the lowest score 22. Based on the research data, which was processed by using SPSS 16.0 For Windows, the result of analysis of the variable of learning interest, obtained the highest score 81 of the highest possible score of 88 , the lowest score of 43 of the lowest possible score of 22 . Based on the results of the analysis obtained mean 63,30 , median of 63.00 , mode 58 and the standard deviation is 7.108. The students who have the tendency of excellent Learning Interests were 17 students $(13 \%)$, students who have the tendency of good learning interest were 100 students (76.3\%), students who have the tendency of less learning interest were 14 students $(10.7 \%)$ and no students who have the tendency of poor learning interest or $0 \%$. By analyzing the propensity score of variables of learning interest of students grade VIII MTs NU Salam showed that the tendency of variable of learning interest is included in the good category.

The data of Parents Social Support variable was obtained from the Parents questionnaire consists of 24 items of questions. The maximum score given is 4 and the minimum score is 1 , therefore, obtained the highest ideal score is 96 and the ideal lowest score is 24. Based on the research data, which was processed by using SPSS 16.0 For Windows, it was found that the variable of Parents Social Support Parents obtained the highest score is 96 and the lowest score is 58. Based on the results of the analysis obtained mean 76,87, median 77.00, mode 75 and the standard deviation of is 6,906. Variable of Parents Social Support Parent can be made to determine the range of scores and the number of respondents who included in the category of very low, low, high, very high. Based on the calculations that can be found in the appendix 5 page 136, obtained the ideal mean of 60 and the ideal standard deviation is 12 , meanwhile, the highest ideal score is 96 and the lowest ideal score is 24 . The students who have a tendency of very high Parents Social Support were 59 students $(45.0 \%)$, students who have a tendency of high Parents Social Support 
were 70 students (53.5\%), students who have a tendency of low high Parents Social Support were 2 students $(1.5 \%)$ and no students who have the tendency of very low parents social support or $0.0 \%$. By analyzing the propensity score of variables of parent's social support of students grade VIII MTs NU Salam Magelang in the Academic Year of 2017/ 2018 indicated that the tendency of variable of parent's social support is included in the high category.

Normality test was used to determine whether the distribution of each independent variable has a normal distribution or not. The testing of normality test was performed by using SPSS 16.0 for Windows. We can be seen that the p-value of each variable is greater than 0.05 at the $5 \%$ significance level, therefore, all variables were normally distributed. Linearity test was used to determine whether each independent variable $(\mathrm{X})$ and the dependent variable $(\mathrm{Y})$ has a linear relationship or not. Is stated to be linear if the increase in the independent variable score followed by the increase in the dependent variable score. We can be seen that both $F_{\text {value }}$ is smaller than $F_{\text {table }}$ at a significance level of $5 \%$, therefore, the relationship between independent variables and the dependent variable is linear.

Multicollinearity test was conducted as a requirements of multiple regression analysis. This is to test whether there is multicollinearity between independent variables which is done by finding out the score of intercorrelations between independent variables. The test results between independent variables showed that there is an intercorrelation (relationship) of 0.121 . Therefore, multicollinearity is not happened since the score does not exceed 0,700 . Based on this result, multiple regression analysis can proceed.

The first hypothesis to be tested in this study is that there is a positive effect of Learning Interest on Social Studies Learning Outcomes. To test the hypothesis, a simple regression analysis was conducted. The following is the summary of the results of a simple regression test of variable Learning Interest on Social Studies Learning Outcomes.

TABLE I. THE SUMMARY OF SIMPLE REGRESSION ANALYSIS $\left(\mathrm{X}_{1}-\mathrm{Y}\right)$

\begin{tabular}{|c|c|c|c|c|c|c|}
\hline \hline variables & Koef & $\begin{array}{c}\mathbf{r x} \\
\mathbf{1 y}\end{array}$ & $\begin{array}{c}\mathbf{r 2 x 1} \\
\mathbf{y}\end{array}$ & $\begin{array}{c}\mathbf{t} \\
\text { arithme } \\
\text { tic }\end{array}$ & ttabel & $\begin{array}{c}\text { Informa } \\
\text { tion }\end{array}$ \\
\cline { 1 - 5 } constants & $\begin{array}{c}52 \\
401\end{array}$ & 03 & 0100 & 3,791 & 1,658 & significant \\
\cline { 1 - 5 } $\mathrm{X}_{1}-\mathrm{Y}$ & 0375 & 17 & & & & Positive \\
\end{tabular}

The correlation coefficient $\left(\mathrm{r}_{\mathrm{x} 1 \mathrm{y}}\right)$ showed a positive result of 0.317 which means the relationship between the variables of Learning Interest on Social Studies Learning Outcome is positive. The coefficient of determination $\left(\mathrm{r}_{2 \times 1 y}\right)$ of 0.100 indicated that the Learning Interest has contributed influence on Social Studies learning outcomes at $10.0 \%$. Significance testing of simple regression by using $t$ test Based on the results of analysis, obtained a significant value of $t$ for the variable of Learning Interest with $t_{\text {value }} 3.791$ greater than $t_{\text {table }} 1,658$ which means that the effect Learning Interest on IPS Learning outcomes is significant. Simple Linear Regression Line Equations $Y=0,375 X_{1}+52.401$. The value of coefficient of variable $\mathrm{X}_{1}$ is 0.375 , it means that if the variable of Learning Interest $\left(\mathrm{X}_{1}\right)$ is increased on one unit then the value of Social Studies learning outcomes (Y) will increase by 0.375 . The $\mathrm{R}_{\text {value }}$ of 0.317 greater than $\mathrm{r}_{\text {table }}$ at $\mathrm{N}=131$ of 0.172 stated that the first hypothesis that there is a positive effect of Learning Interest on Social Studies Learning Learning Outcomes is accepted. Therefore, it is concluded that there is a positive and significant effect Learning Interest on Social Studies Learning Outcomes.

The second hypothesis to be tested in this study is that there is a positive effect of the Parents Social Support on Social Studies Learning Outcomes. To test the hypothesis, a simple regression analysis was conducted. The following is the summary of the results of a simple regression test of variable Parents Social Support on Social Studies Learning Outcomes.

TABLE II. SUMMARY OF SIMPLE REGRESSION ANALYSIS $\left(\mathrm{X}_{2}-\mathrm{Y}\right)$

\begin{tabular}{|c|c|c|c|c|c|c|}
\hline variables & Koef & $\begin{array}{c}\mathbf{r x 2} \\
\mathbf{y}\end{array}$ & $\begin{array}{l}\text { r2 } \\
\text { x2 } \\
\text { y }\end{array}$ & $\begin{array}{c}\mathbf{t} \\
\text { arithmetic }\end{array}$ & ttabel & $\begin{array}{c}\text { Informat } \\
\text { ion }\end{array}$ \\
\hline constants & $\begin{array}{r}43 \\
412 \\
\end{array}$ & & & & & Positive \\
\hline $\mathrm{X} 2-\mathrm{Y}$ & 0426 & $\begin{array}{r}034 \\
9\end{array}$ & $\begin{array}{l}01 \\
22\end{array}$ & 4,234 & 1,658 & significant \\
\hline
\end{tabular}

The correlation coefficient $\left(\mathrm{r}_{\mathrm{x} 2 \mathrm{y}}\right)$ showed a positive result of 0.349 which means the relationship between the variables of Parents Social Support on IPS Learning Outcomes is positive. The coefficient of determination $\left(\mathrm{r}_{2 \mathrm{x} 1 \mathrm{y}}\right)$ is 0.122 indicated that Parents Social Support have contributed influence on Social Studies learning outcomes at $12.2 \%$. The value of significant $t$ for the variable of Parents Social Support obtained $\mathrm{t}_{\text {value }} 4.234$ greater than $\mathrm{t}_{\text {table }} 1,658$ which means that the effect of Parents Social Support on Social Studies learning outcomes is significant. The Simple Linear Regression Line Equations Y $=0.426$ $\mathrm{X}_{2}+43.412$. The value of coefficient of variable $\mathrm{X}_{2}$ of 0.426 means that if Parents Social Support $\left(\mathrm{X}_{2}\right)$ increase on one unit, then the value of Social Studies learning outcomes IPS (Y) will increase by 0,426. The $r_{\text {value }}$ to 0.349 greater than $r_{\text {table }}$ at $\mathrm{N}=131$ of 0.172 , stated that the second hypothesis testing is that there is a positive effect of Parents Social Support on Social Studies Learning Outcomes is accepted. In conclusion, there is a positive and significant effect of Parents Social Support on IPS Learning Outcomes. 
The third hypothesis to be tested in this study is that there is a positive effect of Learning Interest and Parents Social Support simultaneously on IPS Learning Outcomes. The Summary of the results of multiple regression analysis can be seen in the following table 12 :

TABLE III. THE SUMMARY OF RESULTS OF MULTIPLE REGRESSION ANALYSIS $\left(\mathrm{X}_{1} \& \mathrm{X}_{2}-\mathrm{Y}\right)$

\begin{tabular}{|c|c|c|c|c|c|c|}
\hline Source & Koef & $\begin{array}{c}\text { Ry } \\
(1,2)\end{array}$ & $\begin{array}{l}\text { R2y } \\
(1,2)\end{array}$ & $\begin{array}{l}\mathbf{F}_{\text {ari }} \\
\text { thme }\end{array}$ & $\underset{\text { tabel }}{F}$ & Ket. \\
\hline $\begin{array}{c}\text { constant } \\
\text { s }\end{array}$ & $\begin{array}{c}25 \\
714 \\
\end{array}$ & \multirow{3}{*}{0445} & \multirow{3}{*}{0198} & \multirow{3}{*}{$\begin{array}{c}15 \\
834\end{array}$} & \multirow{3}{*}{3070} & \multirow{3}{*}{$\begin{array}{l}\text { Positive } \\
\text { Significant }\end{array}$} \\
\hline $\mathrm{X} 1-\mathrm{Y}$ & 0330 & & & & & \\
\hline $\mathrm{X} 2-\mathrm{Y}$ & 0384 & & & & & \\
\hline
\end{tabular}

Source: Primary data processed

The results of Ry $(1,2)$ of 0.445 indicated a positive value, which means that the relationship of variables Learning Interest and Parents Social Support simultaneously on Social Studies learning outcomes is positive. Based on the results of the calculation, obtained R2y the coefficient of determination (1.2) of 0.198 . This means that $19.80 \%$ of the change in the variable of Social Studies Learning Outcomes (Y) can be explained by the variable of Learning Interest (X1) and Parents Social Support (X2), meanwhile, the remaining $80.20 \%$ is explained by other variables which are not examined in this study. Based on the calculation, obtained significance $F_{\text {value }}$ of $15.834 \mathrm{~s}$ greater than $F_{\text {table }}$ of 3,070 , which means that the effect of variable Learning Interest and Parents Social Support simultaneously on Social Studies learning outcomes is significant. Based on the calculations, obtained the value of coefficient variable learning interest of 0.330 and the value of coefficient of variable Parents Social Support of 0,384 and a constant number of 25.714. The Regression model formed is $\mathrm{Y}=0.330 \mathrm{X} 1+0,384 \mathrm{X} 2+25.714$.

The equation showed the value of coefficient of variable Learning Interest of 0.330 , which means that if the variable of Learning Interest (X1) is increased on one unit, then the value of IPS learning outcomes (Y) will increase by $0.330 \mathrm{BY}$ assuming that Parents Social Support (X2) remains constant. The value of coefficient of the use of variable Parents Social Support $\left(\mathrm{X}_{2}\right)$ of 0,384 means that if the variable of Parents Social Support $\left(\mathrm{X}_{2}\right)$ is increased on one unit, then the value of IPS Learning outcomes (Y) will be increased by 0,384 , by assuming that the variable of Learning Interest $\left(\mathrm{X}_{1}\right)$ remains constant. The $r_{\text {value }}$ obtained is 0,445 greater than $r_{\text {table }}$ at $0.172 \mathrm{~N}=131$ stated that the third hypothesis is that there is a positive effect of Parents Social Support and Learning Interest simultaneously on Social Studies Learning Outcome is accepted. In conclusion, there is a positive and significant effect of Learning Interest and Parents Social Support simultaneously on Social Studies Learning outcomes.
Based on the results of multiple regression analysis, the magnitude of Relative Contribution (SR) and Contribution Effective (SE) of each independent variable on the dependent variable can be determined. The Variable of Learning Interest on Social Studies Learning outcomes is $44.43 \%$ and Parents Social Support is $55.57 \%$. The Effective contribution value for the variable of Learning interest on Social Studies learning outcomes is $8.80 \%$ and Parents Social Support is $11.00 \%$. Simultaneously, variable of learning Interest and Parents Social Support contribute effectively on Social Studies Learning outcomes of $19.80 \%$, whereas, the remain $80.20 \%$ is given by other variables which are not examined in this study.

\section{CONCLUSION}

Based on data analysis and discussion, it can be concluded conclusions that there is a positive and significant effect of Learning Interest on IPS Learning Outcomes indicated by the $r_{x 1 y}=0.317 ; r_{2 x 1 y}=0.100$ and $\mathrm{t}=3.791$ greater than $\mathrm{t}_{\text {table }} 1,658$. There is a positive and significant effect of Parents Social Support on IPS Learning Outcomes indicated by $r_{x 2 y}$ $=0.349 ; \mathrm{r}_{2 \times 2 \mathrm{y}}=0.122$ and $\mathrm{t}=4.234$ greater than $\mathrm{t}_{\text {table }}$ 1,658. There is a positive and significant effect of Learning Interest and Parents Social Support simultaneously of Social Studies Learning Outcomes indicated by $\mathrm{R}_{\mathrm{y}(1,2)}=0.445 ; \mathrm{R}_{2 \mathrm{y}(1,2)}=0.198$ and $\mathrm{F}_{\text {value }}$ $=15.834$ greater than $F_{\text {table }}$ of 3,070. The relative contribution of variable Learning interest on IPS Learning outcomes at $44.43 \%$ and the variable of parents Social Support on Social Studies Learning Outcomes at $55.57 \%$. The Effective contribution of variable Learning interest on Social Studies Learning Outcomes is $8.80 \%$ and the variable of Parents Social Support at $11.00 \%$. Learning interest and Parents Social Support simultaneously provide the effective contribution of $19.80 \%$ to the Learning Outcomes of Social Studies S.

It has been proven that there is a positive and significant effect of learning Interest on Social Studies Learning outcomes. This showed that the better of learning Interest, the higher the Learning Outcomes of Social Studies, so that the necessary efforts, especially schoolteachers to communicate to students to increase interest in learning to help improve learning outcomes. It has been proven that there is a positive and significant effect of Parents Social Support on Social Studies Learning Outcomes. This suggests that the higher Parents Social Support, then the higher the Learning Outcomes of Social Studies, so that the necessary efforts to improve Parents Social Support of students to help improve the learning outcomes of Social Studies. It has been proven that there is a positive and significant effect of learning Interest and Parents Social Support simultaneously on IPS Learning Outcomes. This showed that the higher the Learning interest and Parents Social Support, then the higher the Learning 
Outcomes of Social Studies. It is therefore expected not just from the teachers who play an active role so that students have an interest in learning, but parents also need to continue to give social support to their children in order to increase the maximum Social Studies Learning Outcomes.

\section{REFERENCES}

[1] Arikunto, S. Prosedur Penelitian suatu Pendekatan Praktek. Jakarta: Rineka Cipta. 2013.

[2] Elmgern, M., Ho, F., Akesson, E., Schmid, S., \& Towns, M.,. Comparison and Evaluation of Learning Outcomes from an International Perspective: Development of a Best Practice Process. Journal of Cemical Education, 2015. 92(3). from http://dx.doi.org/10.1021/ed500542b

[3] Lee, Y.J, Chao, C.H \& Chen, C.Y The influences of interest in learning and learning hours on learning outcomes of vocational college students in Taiwan: using a teacher's instructional attitude as the moderator. Global Journal of Engineering Education, 2011. (13)3. Retrieved from http://www.wiete.com.au/journals/GJEE/Publish /vol13no3/01-Lee-Y-J.pdf
[4] McCoach, D.B., Gable, K.R. \& Madura, J.P. Instrument Development in the Affective Domain: School and Corporate Applications 3rd ed. Amazon: Global Priority Shipping. 2013.

[5] Nitko, J.A., \& Brookhart, S.M. Educational Assessment of Students. Pearson/Allyn \& Bacon. 2011.

[6] Reber, A. S. Musing on Brooksian representationalism: A eulogy. Canadian Journal of Experimental Psychology, 64, 382-385. 2010.

[7] Sapriya. Pendidikan IPS: Konsep dan Pembelajaran. Bandung: PT Remaja Rosdakarya Offset. 2015.

[8] Shen, B., Centeio, E., Garn, A., Martin, J., Kulik, N., Somers, C., \& Caughtry, N.M. Parental social support, perceivd competence and enjoyment in school physical activity. Journal of Sport an Health Science. 2017. from https://doi.org/10.1016/j.jshs.2016.01.003.

[9] Taylor, E.S. Health Psychology. $5^{\text {ed }}$. New York: Mc.GrawHill Companies. Inc. 2012

[10] Walen,.R.H \& Lachman, M.E.Social Support and Strain form Partner, Family and Friends: Costs and Benefit for Men and Women in Adulthood, 2000. 19(1) 5-30. from https://www.midus.wisc.edu/ findings/ pdfs/260.pdf 